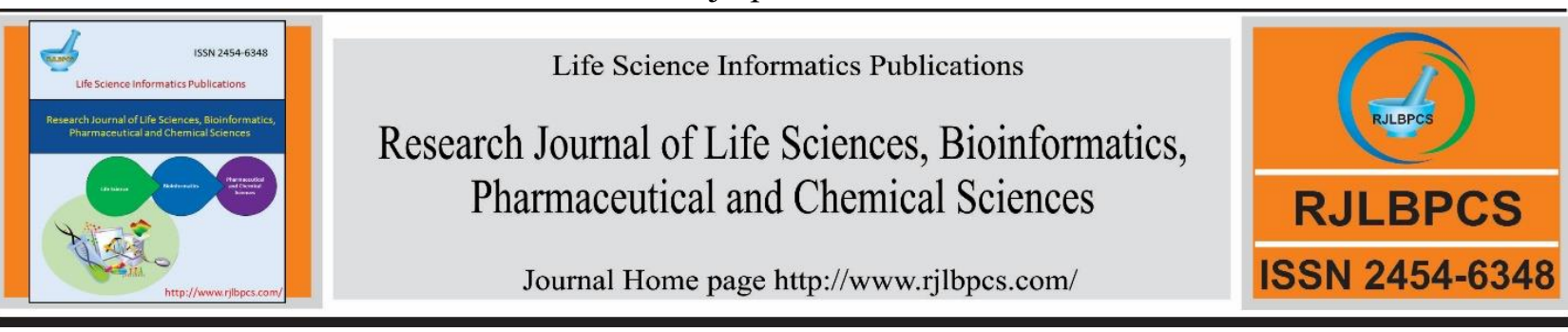

Original Review Article

DOI: $10.26479 / 2019.0502 .57$

AN OVERVIEW OF KUSUM BASED BIODIESEL: AN OPTIMUM FUEL

Ritik Saxena

Dept. of chemistry, Uttaranchal University, Dehradun, Uttarakhand, India.

\begin{abstract}
Energy consumption is increasing very fast. In future the suppy of fossil fuel of the world will be reduced. The rate of the energy consumption is increasing. Suppy is decreasing. Resulting in inflation and lack of energy. This is called energy crisis. The alternate energy sources are required to fulfill for the future prosperity. The kusum oil was produced using a two stage esterification cum transesterification process as the free fatty acid content of the oil was high. The study can be concluded that kusum oil is promising feedstock for the production of biodiesel. Various types physical and chemical parameter of kusum oil and evaluate fatty acid methyl ester has been tested to confirm its conveniences as biodiesel fuel. The viscosity of kusum oil is very high. So it was reduced by transesterification process.
\end{abstract}

KEYWORDS: Kusum oil, transesterification, blending, free fatty acid, biodiesel.

\title{
Corresponding Author: Ritik Saxena*
}

Dept. of chemistry, Uttaranchal University, Dehradun, Uttarakhand, India.

Email Address: saxenaritik70@gmail.com

\section{INTRODUCTION}

Biodiesel can be produced both edible and non edible seed like sunflower, rapeseed, palm, rubber seed etc. many vegetable oil are edible in nature, continuous use of this oil causes lack of food suppy[25]. Biodiesel is a monoalkyl ester that is produced through transesterification process. Transesterification process shows that the conversion of esters in the presence of acid and base as a catalyst [26]. In the production of biodiesel, the product is a mixture of fatty acid and glycerol. Methyl ester of vegetable oil is known as biodiesel [24]. Due to their low speed is becoming increasingly popular environmental impact and capacity as a green alternative fuel for diesel engine. Biodiesel cannot be used for purely for combustion due to high viscosity and low calorific value [1]. There are various benefits of biofuel on fossil fuel. Biofuel is a clean resource of energy because it

(C) 2019 Life Science Informatics Publication All rights reserved

Peer review under responsibility of Life Science Informatics Publications 

controls the insignificant quantity of sulphur, ash, nitrogen. They produce low emission of sulphur dioxide $\left(\mathrm{SO}_{2}\right)$, nitrogen dioxide $\left(\mathrm{NO}_{2}\right)$. In the first generation biofuel, [23] biodiesel from vegetable oils and bio-ethanol from plants. However due to lack of availability of permanent feedstock, an imbalance between society and food industry [2]. Diesel produced in biodiesel have similar properties from crude oil. It is biodegradable. The botanical name of kusum seed is scheichera oleosa [21]. The capacity of the kusum seed is 66000 tonns per year. In india 4000-5000 are collected. It is size very large and it is a long height and fast growing tree up to 35-40 feet. This is mainly found in sub himalaya in north. Flower fall from february to april and the produces fruit in june and july [20]. Kusum oil is extracted from the kusum seed and fatty acid profile shows that it is $40 \%$ unsaturated fatty acid and 53\% saturated fatty acid. Due to high degree better oxidative stability of saturation is better [22]. Due to presence of less free fatty acid content [3]. Various type of vegetables oil sources, non edible oils are convenient for production of biodiesel. Because edible oil is already in demand and is very costly compared to diesel fuel [27]. Non edible oil source such as jatropha, karanjan, mahua, rice husk and tumba are identified as possible biodiesel source and correspond with other source [19]. Which has added benefits to the world tropical and subtropical areas as fast growth, high seed productivity [4]. After methylation fatty acid composition are characterized by GC/MS. The flash point of the biodiesel is higher than the diesel fuel but viscosity and density are found near diesel [18]. If the performance of biodiesel can be improved of the concentration of esters in biodiesel is lower [5]. On the use of biodiesel in the form of fuel in diesel [17]. The engines have seen a reduction in smoke, particle matter, sulphur and carbon compared to diesel, oxidation of hydrocarbon. Another option for reducing emission and improving thermal efficiency is oxygen content of fuel [6].

\section{Transesterification}

Transesterification process, the seeds of non edible vegetable oil are that they contain high free fatty acid and are not convenient as a feed stock for the production of biodiesel by conventional alkaline transesterification method [16]. The transesterification reaction proceeds with catalyst or without catalyst by using primary or secondary monohydric aliphatic alcohols [7].

\section{$\mathrm{RCOOR}^{1}+\mathrm{R}^{2} \mathrm{OH} \leftrightarrow \mathrm{RCOOR}^{2}+\mathrm{R}^{1} \mathrm{OH}$}

\subsection{Acid Esterification}

The kusum oil contains $\mathrm{KOH} / \mathrm{g}$ of free fatty acids (FFA). This is higher than alkaline transesterification [15]. Hence acid esterification was performed to reduce the content of free fatty acid of the feed stock and methanol 6:1 molar ratio is used for esterification in the presence of 1\% $\mathrm{H}_{2} \mathrm{SO}_{4}$ as a catalyst and resulting product obtained from acid esterification are separated by separated funnel at constant stirring [14].

(C) 2019 Life Science Informatics Publication All rights reserved

Peer review under responsibility of Life Science Informatics Publications

2019 March - April RJLBPCS 5(2) Page No.782 


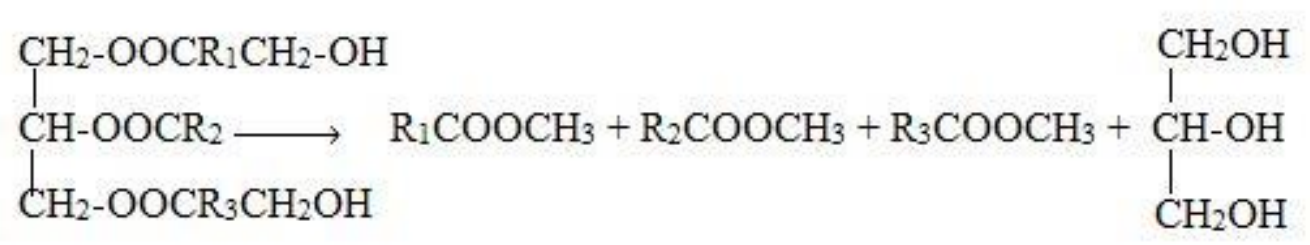

\subsection{Alkaline Transesterification}

The process in which pottassium hydroxide $(\mathrm{KOH})$ is dissolved methanol 6:1 is mixed in molar ratio and then in oil [28]. The reactants were heated and shaken together for 1 hour in reactor [13]. The resulting product was separated by separating funnel. The product was immediately extinguished with ortho phosphoric acid as a catalyst and take part in the reaction and conversion in the feedstock of biodiesel [30]. A light color after a few hours' products biodiesel and glycerol were formed [12]. Settled on glycerol was dropped down and later. Water washing is used to reduce the level of methanol and free glycerol in the required EN 14214 standard compliance level and was adopted study and then completely washed with phosphoric acid [8]. The production of biodiesel is done by transesterification which is a process of using ethanol and methanol in the presence of catalyst such as $\mathrm{KOH}, \mathrm{NaOH}$, [29] chemically breaks oil and fat in ester and glycerol is take part in reaction to remove the glycerine which is a product of biodiesel production [1]. The reaction is carried out by different type of methanol to oil and different type of temperature [11]. The properties of fuel namely, density, kinematic viscosity, flash pour, pour point, water content, carbon residue, ash content, acid value and calorific value of kusum oil, kusum biodiesel and conventional diesel were determined as per standard assigned by ASTM for comparison with the latest American and European standards [3]. The process was continued until the decrease in weight of ester was constant. So the confirm the complete removal of unreacted methanol [10].

\section{CONCLUSION}

The production of biodiesel from kusum seeds, it will help commercializing the product and lack the import of crude oil will help our economy. We have reduced oil viscosity diesel without using any external power source. The viscosity of kusum oil was reduced by preheated to $100-150^{\circ} \mathrm{c}$. $\mathrm{KOME}$ is one of the potential feedstock for biodiesel production.

(C) 2019 Life Science Informatics Publication All rights reserved Peer review under responsibility of Life Science Informatics Publications 


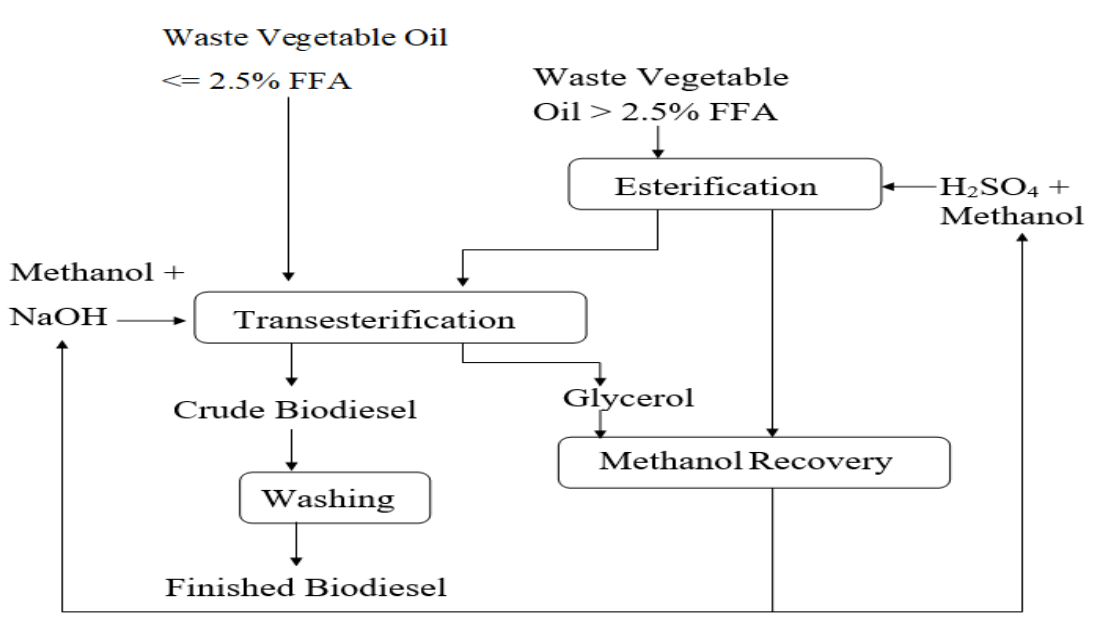

\section{CONFLICT OF INTEREST}

Authors have no any conflict of interest.

\section{REFERENCES}

1. Bhargavi N., Reddy A.V. Krishna. Performance and Emissions Analysis of Kusum Oil Methyl Ester with Air Pre Heating on C.I Engine. International Journal of scientific engineering and research. 2015; $3: 27-31$.

2. Koul Mithlesh, Shadangi Krushna Prasad, Mohanty Kaustubha. Thermo-chemical conversion of Kusum seed : A possible route to produce alternate fuel and chemicals. Journal of Analytical and applied Pyrolysis. 2014; 110: 291-296.

3. Murmu Rabiranjan, Sutar Harekrushna, Patra Sangram. Experimental Investigation and Process and Optimization of Biodiesel Production from Kusum Oil Using Taguchi Method. Advance in Chemical Engineering and Science. 2017; 7: 464-476.

4. Rathod N.P., Lawankar S.M. Experimental Investigation on Use of Methyl Ester Kusum Oil and Its Blends In Direct Injection Ci Engine. IOSR Journal of Mechanical and Civil Engineering. 2013; 10: 36-43.

5. Mohapatra Sudhansu Bhusan, Das Premananda, Mohanty Ramesh Chandra, Swain Dhaneswar. Non-Edible Kusum Oil: Potential Foliage of Biodiesel Production and Its Productive Use in Marine Engines. International Journal of Research in Engineering and Technology. 2016; 4 : 25 36.

6. Jawre Sandip S., Lawankar S.M.. Performance Analysis of Kusum Methyl Ester as Alternative Bio-Fuel in Diesel Engine with Diethyl Ether as Additive. International Journal of Innovative Research \& Development. 2014; 3 : 139-144.

(C) 2019 Life Science Informatics Publication All rights reserved Peer review under responsibility of Life Science Informatics Publications 
7. Prajapati Bhupendra Kumar, Paikra Ajay Singh, Mondoe Dilbag Singh. A comparative evaluation of physical and chemical characterstics of biofuel synthesised from kusum oil and its blends with diesel. International journal of Engineering and Technology. 2018; 5: 1066-1068.

8. Sharma Y.C., Singh Bhaskar. An ideal feedstock, kusum (Schleichera triguga) for preparation of Biodiesel : Optimization of parameters. Fuel. 2010; 89: 1470-1474.

9. Yadav A.K.. Optimum Production of Biodiesel from an Underutilized and Potential Feed Stock Kusum Seed Oil. Iranica Journal of Energy and Envirnment. 2017; 8: 6-10.

10. Sarve Antaram, Varma Mahesh N., Sonawane Shriram S.. Optimization and Kinetic Studies on Biodiesel Production from Kusum (Schleichera triguga) Oil Using Response Surface Methodology. Journal of Oleo Science. 2015; 64 : 987-997.

11. E. M. Shahid and Y. Jamal. A review of biodiesel as vehicular fuel. Renewable and Sustainable Energy review. 2008; $12: 2484-2494$.

12. ASTM D 6751-12. Standard specification for biodiesel fuel blend stock (B100) for middle distillate fuels, West Conshohocken, United States of America, ASTM International, 2012.

13. P. P Oh, H. L. N. Lau, J. Chen, M. F. Chong and Y. M. Choo. A review on conventional technologies and emerging process intensification (PI) methods for biodiesel production. Renewable and Sustainable Energy Review. 2012; 16 : 5131-5145.

14. L. C. Meher, D. V. Sagar and S. N. Naik. Technical aspects of biodiesel production by transesterification a review. Renewable and Sustainable Energy Review. 2006; 10: 248-268.

15. Fang H. and McCormick R. Spectroscopic Study of Biodiesel Degradation Pathways. SAE Technical Paper Series. 2006; 01: 3300.

16. Z. Helwani, M. R. Othman, N. Aziz, W. J. N. Fernado and J. Kim. Technologies for production of biodiesel focusing on green catalytic technique: A Review. Fuel Processing Technology. 2009; 90: 1502-1514.

17. M. J. Climet, A. Corma, P. D. Frutos, S. Iborra, M. Noy, A. Velty and P. Concepcion. Chemicals from biomass: synthesis of glycerol carbonate by transesterification and carbonylation with urea with hydrotalcite catalysis. The role of acid-base pairs. Journal of catalysis. 2010; 269 : 140-149.

18. M. B. Gawande, R. K. Pandey, and R. V. Jayaram. Role of mixed metal oxides in catalysis scienceversalite applications inorganic synthesis. Catalysis Science \& Technology. 2012; 2: 1113-1125.

19. A. K. Singh and S. D. Fernado. Transesterification of Soyabean Oil Using Heterogeneous Catalysis. Energy \& Fuels. 2008; 22: 2067-2069.

20. M. Kouza and J. Hidaka. Transesterification of vegetable oil into biodiesel catalysed by CaO: A review. Fuel. 2012; 93: 1-12.

21. M. Kim, H. Lee, S. J. Yoo, Y. Youm, Y. H. Shin and Y. Lee. Simultaneous synthesis of biodiesel and zinc oxide nanoparticles using supercritical methanol. Fuel. 2013; 109: 279-284.

(C) 2019 Life Science Informatics Publication All rights reserved Peer review under responsibility of Life Science Informatics Publications 
22. R. I. Kusuma, J. P. Hadinoto, A. Ayucitra, F. E. Soetaredjo and S. Ismadji. Natural zeolite from Pacitan Indonesia as catalyst support for transesterification of palm oil. Applied Clay Science. 2013; $74: 121-126$.

23. A. Islam, Y. H. Taufiq-yap, C. Chu, E. Chan and P. Ravindra. Studies on design of heterogenous catalysts for biodiesel production. Process Safety amd Envirnmental Protection. 2013; 91 : 131 144.

24. C. Ngamcharussrivichai, P. Totarat, and K. Bunyakiat. $\mathrm{Ca}$ and $\mathrm{Zn}$ mixed metal oxide as a heterogenous base catalyst for transesterification of palm kernel oil. Applied Catalysis A: General. 2008; $341: 77-85$.

25. H. Muthu, V. SathyaSelvabala, T. K. Varathachary, J. Nandagopal, and S. Subramanian. Synthesis of biodiesel from Neel Oil using Sulphated Zirconia via Transesterification. Brazilian Journal of chemical Engineering. 2010; $27: 601-608$.

26. W. Xie, H. Wang, and H. Li. Silica- supported tin oxides as heterogenous acid catalysts for transesterification of soyabean oil with methanol. Industrial \& Engineering chemistry Research. $2012 ; 51: 225-231$.

27. Lee H. V., Juan J. C., B. A. NF, Taufiq-yap Y. H. Heterogenous base catalysts for edible palm and non-edible Jatropha-based biodiesel production. Chemistry Central Journal. 2014; 8 : 1-9.

28. K. F. Yee, J. C. S Wu and K. T. Lee. A green catalyst for biodiesel production fron jatropha oil: optimization study. Biomass Bioenergy. 2011; 35 : 1739-1746.

29. I. Istadi, D. D. Anggoro, L. Buchori, D. A. Rahmawari and D. Intaningrum. Active Acid catalyst of Sulphated Zinc Oxide for transesterification of soyabean oil with methanol to biodiesel. Procedia Envirnmental Science. 2015; $23: 385-393$.

30. M. D. Solikhah, K. Amri, O. Fariza and I. Panyanto. Relation between Parameters in SNI Biodiesel : Total Glycerol, Ester Content, Viscosity and Temperature Distillation on Biodiesel from Palm Oil and Jatropha. Conference; Sriwijaya International Seminar on energy \&Technology. 2010.

(C) 2019 Life Science Informatics Publication All rights reserved Peer review under responsibility of Life Science Informatics Publications 